\title{
VARIABILITY OF HYDRAULIC CONDUCTIVITY DUE TO MULTIPLE FACTORS
}

\author{
Sanjit K. Deb and Manoj K. Shukla \\ Department of Plant and Environmental Sciences, New Mexico State University, \\ MSC 3Q, P.O. Box 30003, Las Cruces, New Mexico 88003, USA
}

Received 2012-05-01, Revised 2012-07-19; Accepted 2012-08-11

\begin{abstract}
Soil properties are greatly influenced by intrinsic factors of soil formation as well as extrinsic factors associated with land use and management and vary both in time and space. Intrinsic variability is caused by the pedogenesis and usually takes place at large time scales. The variability caused by extrinsic factors could take effect relatively quickly and could not be treated as regionalized. Saturated hydraulic conductivity is one of the most important soil properties for soil-water-plant interactions, water and contaminant movement and retention through the soil profile. It is a critically important parameter for estimation of various other soil hydrological parameters necessary for modeling flow through the naturally unsaturated vadose zone. Among different soil hydrological properties, saturated hydraulic conductivity is reported to have the greatest statistical variability, which is associated with soil types, land uses, positions on landscape, depths, instruments and methods of measurement and experimental errors. The variability of saturated hydraulic conductivity has a profound influence on the overall hydrology of the soil system. Therefore, focus of this review is centered on the variability of saturated/unsaturated hydraulic conductivity due to a large number of factors. This study reviews recent experimental and field studies addressing the measurements and variability of hydraulic conductivity. A synthesis of a large amount of data available in literature is presented and the possible sources of the variability and its implications are discussed. The variability of a soil hydraulic conductivity can be expressed by range, interquartile range, variance and standard deviation, coefficient of variation, skewness and kurtosis. The spatial and temporal variability of hydraulic conductivity and the influences of sample support, measurement devices/methods, soils, land uses and agricultural management on hydraulic conductivity are evaluated. Methods of measurements strongly impact variability, for example, saturated hydraulic conductivity measured using a single ring may produce significantly different mean and standard errors than those measured using a double ring. The sample support can also influence the variability, for example, increasing or decreasing the size of the infiltrometer rings can change the mean and variability of the saturated hydraulic conductivity. Similarly, hydraulic conductivity measured in the field could show a much larger variability than those measured in the laboratory. The spatial and temporal variations of hydraulic conductivity and interactions among soil characteristics, land uses, agricultural management, climatic and environmental conditions and measurement methods are rather complex, which should take into account multiple factors discussed in this review. Decisions and choices made by investigators during sampling, sampling designs, availability of resources, number of investigators involved in sampling and analysis, skill level of investigators, type and quality of tools and equipments used to collect samples and analyses, scale of the domain, availability of time, accessibility of sites, criteria of success and assumptions made for the sampling and analysis have profound influence on the variability of hydraulic conductivity.
\end{abstract}

Keywords: Hydraulic Conductivity, Measurement of Hydraulic Conductivity, Variability of Hydraulic Conductivity, Spatial Variability, Temporal Variability

\section{INTRODUCTION}

Darcy's law describes the one dimensional flow of water through a saturated soil profile whereas Darcy-
Buckingham law describes the one dimensional flow of water through an unsaturated soil profile. A more exact and generalized differential form of Darcy's law for three dimensional saturated porous media was proposed by

Corresponding Author: Sanjit K. Deb, Department of Plant and Environmental Sciences, New Mexico State University, MSC 3Q, P.O. Box 30003, Las Cruces, New Mexico 88003, USA 
Slichter (1899). The formulations essentially indicate that the flow through the saturated porous media is proportional to the hydraulic gradient that is the driving force causing flow. And the term, included as a constant of proportionality, is known as hydraulic conductivity $\left(\mathrm{K}_{\mathrm{s}}\right)$ of the saturated porous media (Lal, 2004). In essence the $K_{\mathrm{s}}$ is a constant for a given saturated porous media in any given direction and it can have a different constant value in each of the three dimensions. The $\mathrm{K}_{\mathrm{s}}$ is strongly influenced by the properties of a porous media such as structure, pore connectivity as well as the properties of the fluid such as viscosity and temperature.

Another similar term is permeability that is defined as the property of the porous medium controlled only by the pore geometry (Richards, 1952). Permeability and the hydraulic conductivity are very different parameters. It is believed that Soil Conservation Service handbook first defined qualitatively the water movement through soil as two distinct permeability classes of favorable and unfavorable (Norton, 1939). Subsequently using the percolation field experiments of Uhland and O'Neal (1951), seven permeability classes were proposed (SSDS, 1993). Based upon the work of Mason et al. (1957), National Soil Moisture Committee proposed a "choice schema" of five to seven classes Soil Survey Division, 1997. There were two popular methods at that time, one of them was the auger hole method that can measure water flow in multiple directions and the other was Uhland core method. There were concerns about the suitability of each method and whether these two can provide similar estimates of the permeability. By 1969, saturated hydraulic conductivity obtained from the Darcy's law was recommended as the correct term and permeability classes were renamed as hydraulic conductivity classes.

Saturated hydraulic conductivity is one of the most important parameters for soil-water-plant interactions, water and solute movement and retention through the soil profile. It is a critically important parameter for estimation of various other soil hydrological parameters necessary for modeling flow through the naturally unsaturated vadose zone. Among different soil hydrological properties, the $\mathrm{K}_{\mathrm{s}}$ is reported to have the greatest statistical variability by several authors (Biggar and Nielsen, 1976; Hern and Melancon, 1986; Webb et al., 2000). The variability of $\mathrm{K}_{\mathrm{s}}$ is associated with soil types, land uses, positions on landscape, depths, instruments and methods of measurement and experimental errors (Stockton and Warrick, 1971). It has been suggested that more studies are needed on the variability of $\mathrm{K}_{\mathrm{s}}$ across different landscapes. The variability of $\mathrm{K}_{\mathrm{s}}$ has a profound influence on the overall hydrology of the soil system. Therefore, focus of this review is centered on the variability of saturated/unsaturated hydraulic conductivity due to a large number of factors. A summary of methods of measurements, synthesis of large amount of data available in literature is presented and the possible sources of the variability and its implications are discussed.

\subsection{Methods of Hydraulic Conductivity Determination}

The various laboratory and field methods used in determining the hydraulic conductivity are summarized in Fig. 1. Readers are referred to Schilfgaarde (1974); Dane and Topp (2002); Stephens (1996); Reynolds et al. (2000) and Dane and Topp (2002) for details on the saturated $\left(\mathrm{K}_{\mathrm{s}}\right)$ and unsaturated $(\mathrm{K})$ hydraulic conductivity determination methods.

\subsection{Saturated Hydraulic Conductivity}

The $\mathrm{K}_{\mathrm{s}}$ of undisturbed cylindrical core samples can be measured by using a constant head or a falling head method in the laboratory. Measurements of field $\mathrm{K}_{\mathrm{s}}$ in the unsaturated or vadose zone (above the water table) can be obtained using various ring or cylinder infiltrometers (e.g., single-ring and double-or concentricring infiltrometers, pressure infiltrometers, twin-or dualring and multiple-ring infiltrometers) and constant head well or borehole permeameter methods. The correlation methods are based upon relationships between the $\mathrm{K}_{\mathrm{s}}$ value and one or more of the soil properties such as soil texture, pore size distribution of the soil, grain size distribution of the soil and soil mapping unit. In the saturated zone (below the water table), auger hole and piezometer methods are commonly used techniques. Other methods in the saturated zone include the two-well method, the four-well method, the multiple-well method, the pit bailing test and the slug test.

\subsection{Unsaturated Hydraulic Conductivity}

The laboratory methods are: steady state flow methods in horizontal or vertical column under constant head or flux conditions and transient flow methods. Measurements can also be made in laboratory long soil columns by inducing evaporation or infiltration. A variety of transient laboratory techniques can be used: the instantaneous profile method, the Bruce-Klute method, the pressure plate method, the one-step outflow method and the ultracentrifuge method. The field methods include the instantaneous profile method, the flux control method, the flow net method and the borehole point source method. The crust method can be applied while using double-ring infiltrometers, pressure infiltrometers, or disc permeameters. There are two approaches to estimate the $\mathrm{K}$ function of an unsaturated soil: empirical equations and statistical models (Table 1). Several measured conductivity data are required to use an empirical equation, while a statistical model can be used to predict the $\mathrm{K}$ function when the $\mathrm{K}_{\mathrm{s}}$ and the soil water retention curve are available. 


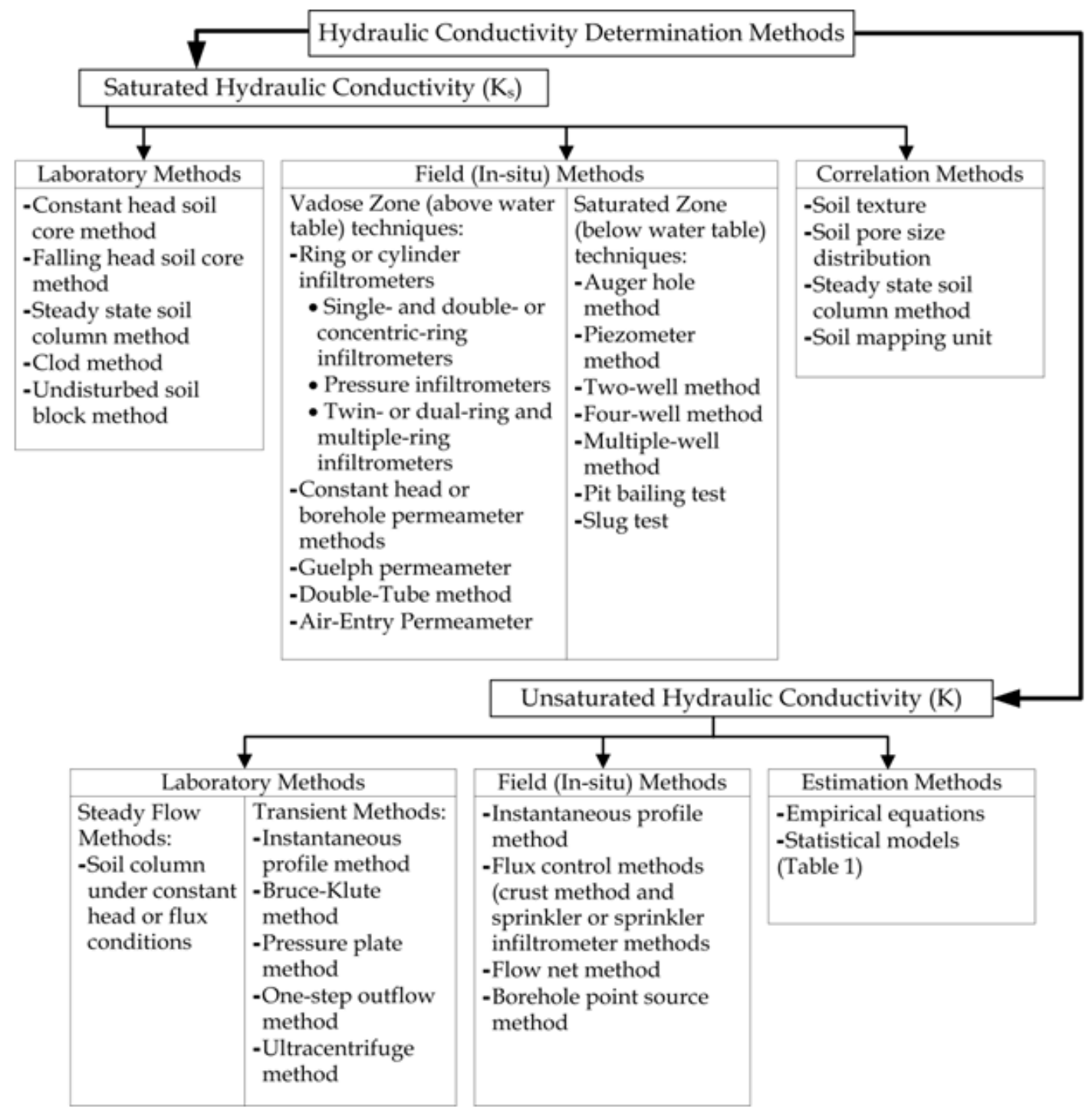

Fig. 1. Overview of methods used to determine the hydraulic conductivity

\subsection{Variability of Soil Hydraulic Conductivity}

Soil hydraulic conductivity displays large statistical variability and both short and long range spatial and temporal variability. It is greatly influenced by extrinsic factors of land use and management, usually at short time scales and the intrinsic factors of soil formation, usually at large time scales (Nielsen et al., 1973). Intrinsic variability, due to pedogenesis, is also known as regionalized with nearby areas being more similar than the areas farther away (Dane and Topp, 2002; Nielsen and Wendroth, 2003). On the other hand, the extrinsic variability could take effect rather quickly and might not be treated as regionalized. In addition to these two sources of variability, measurement devices used, sample support areas, assumptions and choices made by the investigators, types of sampling strategy and designs also have profound influence on the variability.

Methods of measurements strongly impact variability, for example, long term infiltration tests conducted to determine field $\mathrm{K}_{\mathrm{s}}$ using a single ring may produce significantly different mean and standard errors than those measured using a double ring, Guelph permeameter and/or tension infiltrometer at the same location. The sample support or size of the infiltrometer rings or disks also influence the variability. Similarly, hydraulic conductivity measured in the field could show a much different amounts of variability than those measured in the laboratory (Shukla, 2011). 
Table 1.Empirical equations and statistical models for the unsaturated hydraulic conductivity $[\mathrm{K}(\Psi)$ or $\mathrm{K}(\theta)]$

Hydraulic conductivity function Reference

\section{Empirical equations:}

$\mathrm{K}(\Psi)=\mathrm{a} \Psi+\mathrm{b}$, where $\mathrm{a}$

Richards (1931)

and $\mathrm{b}$ are constants

$\mathrm{K}(\theta)=\mathrm{S}^{\mathrm{n}}$, where $\mathrm{n}=3.5$,

$(1962)$

$\mathrm{S}=\left(\theta-\theta_{\mathrm{r}}\right) /\left(\theta_{\mathrm{s}}-\theta_{\mathrm{r}}\right)$

$\mathrm{K}(\Psi)=\mathrm{a}(\Psi)^{-\mathrm{b}}$, where

Polubarinova-Kochina

$\mathrm{a}$ and $\mathrm{b}$ are contants

Wind, (1955)

$\mathrm{K}(\theta)=\mathrm{a} \theta^{\mathrm{n}} ; \mathrm{K}(\Psi)=\mathrm{a} /\left(\mathrm{b}+\Psi^{\mathrm{n}}\right) ; \quad$ Gardner $(1958)$

$\mathrm{K}(\Psi)=\mathrm{K}_{\mathrm{S}} /\left[1+\left(\Psi / \Psi_{\mathrm{C}}\right)^{\mathrm{n}}\right]$

where $\mathrm{a}, \mathrm{b}$ and $\mathrm{n}$ are contants

$\mathrm{K}(\Psi)=\mathrm{K}_{\mathrm{S}}$ for $\Psi \leq \Psi_{\mathrm{aev}} ; \mathrm{K}(\Psi) \quad$ Brooks and Corey (1964)

$=\left(\Psi / \Psi_{\text {aev }}\right)^{-\lambda}$ for $\Psi \geq \Psi_{\text {aev }}$

where $\lambda$ is the pore size

distribution index

$\mathrm{K}(\Psi)=\mathrm{K}_{\mathrm{S}}$ for $\Psi \leq \Psi_{\text {aev }}$

$\mathrm{K}(\Psi)=\exp \left[\mathrm{a}\left(\Psi-\Psi_{\mathrm{aev}}\right)\right]$ for $\Psi_{\mathrm{aev}}$

$\leq \Psi \leq \Psi_{1}$, where a is a constant

$\mathrm{K}(\Psi)=\mathrm{K}(\Psi)_{1}\left(\Psi / \Psi_{1}\right)^{-\mathrm{n}}$ for $\Psi$

$>\Psi_{1}$, where $\mathrm{n}$ is a constant

$\mathrm{K}(\theta)=\mathrm{K}_{\mathrm{S}} \exp \left[\mathrm{a}\left(\theta-\theta_{\mathrm{S}}\right)\right]$,

where $\mathrm{a}$ is a constant

$\mathrm{K}(\theta)=\mathrm{K}_{\mathrm{S}}\left(\theta / \theta_{\mathrm{S}}\right)^{2 \mathrm{~b}+3}$;

$\mathrm{K}(\Psi)=\mathrm{K}_{\mathrm{S}}\left(\Psi_{\mathrm{aev}} / \Psi\right)^{2+3 / \mathrm{b}}$

Davidson et al. (1969)

Rijtema (1965)

where $\mathrm{b}$ is the exponent of moisture release equation

$\mathrm{K}(\theta)=1 /\left\{\mathrm{in}\left[\mathrm{e}+(\Psi / \mathrm{A})^{\mathrm{B}}\right]\right\}^{\mathrm{C}}$

where $\mathrm{e}$ is void ratio and

$\mathrm{a}, \mathrm{b}$ and $\mathrm{c}$ are contants

Statistical models:

$\mathrm{K}(\mathrm{S})=\mathrm{K}_{\mathrm{s}} \mathrm{S} \frac{\mathrm{g}(\mathrm{S})}{\mathrm{g}(1)}$,

Burdine (1953)

In which

$g(S)=\int_{0}^{S} \frac{1}{[\psi(x)]^{2}} d x$

where 1 is the pore-connectivity

parameter $(1=2)$

$K(S)=K_{S} S^{1}\left[\frac{f(s)}{f(1)}\right]^{2}$,

Mualem (1976)

In which

$$
\mathrm{f}(\mathrm{S})=\int_{0}^{\mathrm{S}} \frac{1}{\psi(\mathrm{x})} \mathrm{dx}
$$

Where 1 is the pore-connectivity

parameter $(1=0.5)$

Note: In the Table, $K_{s}$ is the saturated hydraulic conductivity, $\Psi$ is the matric suction head, $\Psi_{\text {aev }}$ is the bubbling or air-entry suction, $\Psi_{\mathrm{c}}$ is the suction head at which $\mathrm{K}=\mathrm{K}_{\mathrm{s}} / 2, \Psi_{1}$ is the soil residual suction and $\mathrm{K}(\Psi)_{1}$ is the $\mathrm{K}(\Psi)$ at $\Psi=\Psi_{1}, \theta$ is volumetric water content, $\theta_{\mathrm{s}}$ is the saturated water content and $\theta_{\mathrm{r}}$ is the residual water content

\subsection{Statistical Variability}

The variability of soil hydraulic conductivity is usually expressed as Coefficient of Variation (CV), ratio of standard deviation and mean. There are several criteria based on $\mathrm{CV}$, a measure of relative variability, available in the literature. Statistical variability can also be represented by variance or standard deviation, range including interquartile range, skewness and kurtosis. Variance is defined as the second moment about mean that is the average of the square of deviations of a value from its mean value or the first moment. Standard deviation is the measure of absolute variability. The difference between the largest and the smallest value is presented as range. If data contains outliers then range does not truly describe the characteristic of the datasets and in that case interquartile range that takes middle 50\% of values is a somewhat better statistic to express variability. Skewness is expressed as the ratio of third moment about mean and third power of standard deviation and kurtosis is the ratio of fourth moment about mean and fourth power of standard deviation. Skewness is a measure of the asymmetry of the probability distribution of a random variable, while kurtosis is a measure of the peakedness of the probability distribution of a random variable (Isaaks and Srivastava, 1989; Nielsen and Wendroth, 2003).

Several studies undertaken during the last decades reported that in general $\mathrm{K}_{\mathrm{s}}$ displays the greatest variability expressed as CV across sites (Table 2), although some of the important on site hydraulic properties affecting $\mathrm{K}_{\mathrm{s}}$ such as total porosity and field capacity water content could have much smaller variability (data not reported) across these sites (Shukla, 2011). Such a behavior supported earlier observations that pore size, shape and connectivity are more important than total porosity.

\subsection{Influence of Sample Support on Saturated Hydraulic Conductivity}

Among various factors influencing variability of $\mathrm{K}_{\mathrm{s}}$, the sample support or the area of cross section of the flow domain is an important factor (Bagarello, 1997). Gupta et al. (2006) reported only minor differences in $\mathrm{K}_{\mathrm{s}}$ when infiltration tests were performed in field near College Station, Texas using disk infiltrometer with disk sizes of $10,15,17,20$ and $24 \mathrm{~cm}$. The CVs for the $\mathrm{K}_{\mathrm{s}}$ ranged from 0.3-0.5 for disk sizes ranging from 0.10$0.17 \mathrm{~m}$. However, further increase in the disk sizes to 0.20 and $0.25 \mathrm{~m}$ resulted in a much higher increases in CVs to 0.87 and 0.86 , respectively (Table 3). Not much difference was observed in the mean value of the $\mathrm{K}_{\mathrm{s}}$ and no relationship was observed between disk size and $\mathrm{K}_{\mathrm{s}}$. The larger variability for bigger disks could be due to the inclusion of larger sample volume with attendant increase in heterogeneity and macropore network. 
Table 2. The statistical variability of saturated hydraulic conductivity $\left(\mathrm{K}_{\mathrm{s}}{ }_{\mathrm{s}}, \mathrm{cm} \mathrm{h}^{-1}\right)$ for some sites within the United States

\begin{tabular}{|c|c|c|c|c|c|c|c|c|c|}
\hline Mean & Median & SD & $\mathrm{CV}$ & Min & Max & Range & Skewness & Kurtosis & Location \\
\hline $\begin{array}{l}\text { Shukla et al. (2003a): } \\
84\end{array}$ & 72.1 & 85.90 & 1.0 & 0.6 & 327.0 & 327.0 & 2.3 & 6.4 & Columbus, Ohio \\
\hline $\begin{array}{l}\text { Shukla et al. (2003b): } \\
13.9 \\
\text { Iqbal et al. (2005): }\end{array}$ & 7.3 & 16.78 & 1.2 & 0.1 & 86.9 & 86.8 & 3.1 & 12.1 & Coshocton, Ohio \\
\hline $\begin{array}{l}1 \\
0.3 \\
0.5\end{array}$ & $\begin{array}{l}0.4 \\
0.1 \\
0.2\end{array}$ & $\begin{array}{l}1.60 \\
0.40 \\
0.90\end{array}$ & $\begin{array}{l}1.6 \\
1.5 \\
1.7\end{array}$ & $\begin{array}{l}0.0 \\
0.0 \\
0.0\end{array}$ & $\begin{array}{r}11.8 \\
2.6 \\
6.4\end{array}$ & $\begin{array}{r}11.8 \\
2.6 \\
6.4\end{array}$ & $\begin{array}{l}3.5 \\
3.0 \\
3.6\end{array}$ & $\begin{array}{l}- \\
- \\
-\end{array}$ & $\begin{array}{l}\text { Perthshire, Mississippi } \\
\text { Perthshire, Mississippi } \\
\text { Perthshire, Mississippi }\end{array}$ \\
\hline $\begin{array}{l}\text { Shukla and Lal (2005): } \\
23.7 \\
\text { Duffera et al. (2007): }\end{array}$ & 18.2 & 21.10 & 0.9 & 1.3 & 64.2 & 62.9 & 1.0 & 0.0 & South Charleston, Ohio \\
\hline $\begin{array}{l}5.3 \\
\text { Ikemura et al. (2008): } \\
0.1\end{array}$ & 2.9 & 5.40 & 1.0 & 0.0 & 22.9 & 22.9 & 1.1 & 0.0 & Kinston, North California \\
\hline
\end{tabular}

${ }^{\S}$ SD: standard deviation; CV: coefficient of variation; Min: Minimum value; and Max: Maximum value

Table 3. Effect of sample support or size $(\mathrm{m})$ of the disk of the permeameter on saturated hydraulic conductivity $\left(\mathrm{K}_{\mathrm{s}}^{\S}, \mathrm{m} \mathrm{s}^{-1}\right)$ of soil (data modified from Gupta et al., 2006)

\begin{tabular}{lllllll}
\hline Disc size & Mean & SD & CV & Max & Min & Range \\
\hline 0.1 & $3.7 \times 10^{-5}$ & $1.9 \times 10^{-5}$ & 0.51 & $5.5 \times 10^{-5}$ & $1.8 \times 10^{-5}$ & $3.7 \times 10^{-5}$ \\
0.15 & $5.9 \times 10^{-5}$ & $1.6 \times 10^{-5}$ & 0.27 & $8.2 \times 10^{-5}$ & $4.6 \times 10^{-5}$ & $3.6 \times 10^{-5}$ \\
0.17 & $6.5 \times 10^{-5}$ & $2.7 \times 10^{-5}$ & 0.40 & $1.0 \times 10^{-4}$ & $4.3 \times 10^{-5}$ & $6.0 \times 10^{-5}$ \\
0.20 & $2.2 \times 10^{-5}$ & $1.9 \times 10^{-5}$ & 0.87 & $5.7 \times 10^{-5}$ & $8.2 \times 10^{-7}$ & $5.6 \times 10^{-5}$ \\
0.24 & $2.1 \times 10^{-5}$ & $1.8 \times 10^{-5}$ & 0.86 & $5.5 \times 10^{-5}$ & $5.7 \times 10^{-7}$ & $5.4 \times 10^{-5}$ \\
\hline
\end{tabular}

${ }^{8}$ SD: Standard Deviation; CV: Coefficient of Variation; Min: Minimum value; and Max: Maximum value

Table 4. Saturated hydraulic conductivity $\left(\mathrm{K}_{\mathrm{s}}^{\S}, \mathrm{m} \mathrm{s}^{-1}\right)$ determined by using the packed soil columns and undisturbed soil samples of different sizes in the laboratory and the Guelph permeameter method under dry and wet antecedent soil water content (Adapted from Bagarello and Provenzano, 1996)

\begin{tabular}{|c|c|c|c|c|}
\hline Method & Arithmetic mean & GM & SD & $\mathrm{CV}$ \\
\hline \multicolumn{5}{|l|}{ Undisturbed Samples": } \\
\hline Large Cores & $4.51 \times 10^{-5}$ & $3.74 \times 10^{-5}$ & $2.81 \times 10^{-5}$ & 0.623 \\
\hline Small Cores & $1.07 \times 10^{-4}$ & $6.34 \times 10^{-5}$ & $1.05 \times 10^{-5}$ & 0.976 \\
\hline \multicolumn{5}{|l|}{ Packed Soil Columns ${ }^{*}$ : } \\
\hline CHP (Large Cores) & $3.03 \times 10^{-6}$ & $3.01 \times 10^{-6}$ & $3.37 \times 10^{-7}$ & 0.111 \\
\hline CHP (Small Cores) & $3.00 \times 10^{-6}$ & $2.98 \times 10^{-6}$ & $4.04 \times 10^{-7}$ & 0.134 \\
\hline \multicolumn{5}{|c|}{ GP (Simultaneous Equations Analysis) ${ }^{\dagger}$ : } \\
\hline Dry soil (SWC < 12\%) & $3.79 \times 10^{-5}$ & $3.00 \times 10^{-5}$ & $2.30 \times 10^{-5}$ & 0.607 \\
\hline Wet soil (SWC $\geq 12 \%$ ) & $7.10 \times 10^{-6}$ & $5.33 \times 10^{-6}$ & $5.95 \times 10^{-6}$ & 0.838 \\
\hline \multicolumn{5}{|c|}{ GP (Single Height Analysis) ${ }^{\dagger}$ : } \\
\hline Dry soil (SWC < 12\%) & $4.19 \times 10^{-5}$ & $3.90 \times 10^{-5}$ & $1.54 \times 10^{-5}$ & 0.368 \\
\hline Wet soil (SWC $\geq 12 \%$ ) & $1.77 \times 10^{-5}$ & $1.39 \times 10^{-5}$ & $1.24 \times 10^{-5}$ & 0.701 \\
\hline
\end{tabular}

${ }^{\S}$ GM: Geometric mean; SD: Standard deviation; and CV: Coefficient of variation; ${ }^{*}$ CHP: Constant head permeameter; and large and small cores were collected in $0.085 \mathrm{~m}$-diameter $\times 0.11 \mathrm{~m}$-high and $0.05 \mathrm{~m}$-diameter $\times 0.05 \mathrm{~m}$-high stainless cylinders, respectively; ${ }^{\dagger} \mathrm{GP}:$ Guelph permeameter; and SWC: Soil water content

In another study, Bagarello and Provenzano (1996) studied the effect of size of the undisturbed soil core on the laboratory estimates of $\mathrm{K}_{\mathrm{s}}$ using Constant Head Permeameter (CHP) method in a sandy clay soil and in particular, large cores $(0.085 \mathrm{~m}$-diameter $\times 0.11 \mathrm{~m}$-high stainless cylinders) produced lower and less variable estimates of $\mathrm{K}_{\mathrm{s}}$ than small cores $(0.05 \mathrm{~m}$-diameter $\times 0.05$ $\mathrm{m}$-high stainless cylinders), in which the preferential flow increased greatly. A comparison between results of the in-situ Guelph Permeameter (GP) method and CHP method showed that overall, $\mathrm{K}_{\mathrm{s}}$ values obtained using CHP method produced larger means and $\mathrm{CV}$ values than $\mathrm{K}_{\mathrm{s}}$ values obtained from the GP method (Table 4).

\subsection{Influence of Measurement Devices/Methods on Saturated Hydraulic Conductivity}

The $\mathrm{K}_{\mathrm{s}}$ can be measured using various devices and procedures as described earlier. The $\mathrm{K}_{\mathrm{s}}$ was determined by conducting long duration infiltration tests $(3 \mathrm{~h})$ using double ring infiltrometers and using constant head 
method on soil cores collected from the same experimental location near Ohio, USA (Shukla et al., 2003b). Table 5 presents the average and standard deviations of $i_{c}$ and $K_{s}$ determined in field and lab, respectively, at three slope positions, shoulder, middle and foot. The hypothesis was that since double ring has a sample support of $15 \mathrm{~cm}$ that is almost double the sample support for the core $(7.8 \mathrm{~cm}), \mathrm{i}_{\mathrm{c}}$ would be much greater than $\mathrm{K}_{\mathrm{s}}$. However, the data in Table 5 does not validate the hypothesis except for the data from No-Till Corn-Soybean-Rotation (NTCSR) field. Earthworm activities were clearly noted in NTM and NTWM fields but sample support did not influence the values of $\mathrm{K}_{\mathrm{s}}$, indicating that macropore channels or earthworm burrows were not open at the soil surface.

However, an exactly opposite result is also possible for a variety of reasons, such as, smaller sample support for laboratory (or core) than the field experiment, spaces between the core and the soil, hitting or missing macropores in the soils. In an experiment, Reynolds et al. (2000) determined $\mathrm{K}_{\mathrm{s}}$ using tension infiltrometer, pressure infiltrometer and soil cores (Table 6). The mean $\mathrm{K}_{\mathrm{s}}$ values were always greater for the soil core method for sand and clay loam soil but not for loam. The smaller $\mathrm{K}_{\mathrm{s}}$ for tension and pressure infiltrometer methods can be because of the fact that in-situ methods mostly have a disadvantage of soils not being fully saturated and measurements are actually under quasi steady state.

In general, looking at the data in Table $\mathbf{5}$ and 6, the variability expressed as $\mathrm{CV}$ of $\mathrm{K}_{\mathrm{s}}$ was large irrespective of the method of measurement and no definite trends were visible among these methods. The possible explanation for the differences among these methods could be the differences in flow domains or sample sizes and flow geometries. The surface area for the infiltration was much higher $\left(491 \mathrm{~cm}^{2}\right)$ for tension infiltrometer than for other methods $\left(79 \mathrm{~cm}^{2}\right)$. Flow was three dimensional from a tension infiltrometer and near one dimensional from a pressure infiltrometer or soil core method. In addition, likely blockage of macropores by core walls and experimental artifacts could also change $\mathrm{K}_{\mathrm{s}}$. For a randomly distributed domain, measuring $K_{s}$ over a larger volume of soil can be equivalent to pooling the measurements from within the smaller volumes (Parkin and Robinson, 1992). In this case the small and large supports are centered on the same mean because they are sampling the same population.

In a study, the $\mathrm{K}_{\mathrm{s}}$ from Guelph permeameter, the velocity permeameter, a pumping test procedure and the auger hole method were compared for a Ravenna silt loam at Wooster and a Hoytville silty clay loam near Fermont, Ohio and evaluations were conducted during high water table conditions established by subirrigation (Dorsey et al., 1990). Authors reported that the pumping test, auger hole and velocity permeameter methods provided results within similar ranges whereas the Guelph permeameter provided significantly lower estimates of $\mathrm{K}_{\mathrm{s}}$ (Table 7).

Table 5. Saturated hydraulic conductivity measured in laboratory $\left(\mathrm{K}_{\mathrm{s}}^{\S}, \mathrm{cm} \mathrm{h}^{-1}\right)$ and field $\left(\mathrm{i}_{\mathrm{c}}, \mathrm{cm} \mathrm{h}^{-1}\right)$ in six fields under different treatments (Shukla et al., 2003b)

\begin{tabular}{|c|c|c|c|c|c|c|}
\hline \multirow[b]{2}{*}{ Treatment* } & \multicolumn{3}{|l|}{$\mathrm{i}_{\mathrm{c}}$} & \multicolumn{3}{|l|}{$\mathrm{K}_{\mathrm{s}}$} \\
\hline & Mean & SD & $\mathrm{CV}$ & Mean & SD & $\mathrm{CV}$ \\
\hline NTM & 9.52 & 5.59 & 0.59 & 13.79 & 9.13 & 0.66 \\
\hline NTWM & 16.13 & 5.41 & 0.34 & 15.53 & 9.82 & 0.56 \\
\hline NTCSR & 24.15 & 6.88 & 0.29 & 4.08 & 3.36 & 0.82 \\
\hline CT & 13.84 & 5.72 & 0.41 & 5.53 & 0.53 & 0.10 \\
\hline M & 10.96 & 8.67 & 0.79 & 37.08 & 4.84 & 0.13 \\
\hline
\end{tabular}

§ SD: Standard Deviation; and CV: Coefficient of Variation; * NTM: No-Till with Manure; NTWM: No-Till Without Manure; NTCSR: No-Till CornSoybean Rotation; CT: Conventional Tillage and M: Meadow

Table 6. Saturated hydraulic conductivity $\left(\mathrm{K}_{\mathrm{s}}^{\S}, \times 10^{-5} \mathrm{~m} \mathrm{~s}^{-1}\right)$ measured in a no-tillage field using three different devices: tension infiltrometer, pressure infiltrometer and soil core methods under three different soils (Reynolds et al., 2000)

\begin{tabular}{|c|c|c|c|c|c|c|}
\hline Device & GM & $\mathrm{CV}$ & Max & Min & Range & Soil \\
\hline Tension & 2.6 & 47.3 & 5.3 & 1.2 & 4.1 & Sand \\
\hline Tension & 4.2 & 68.2 & 16.0 & 2.4 & 13.6 & Loam \\
\hline Tension & 2.3 & 62.8 & 5.1 & 1.0 & 4.2 & Clay loam \\
\hline Pressure & 5.4 & 58.1 & 9.9 & 1.6 & 8.3 & Sand \\
\hline Pressure & 6.9 & 79.5 & 15.7 & 1.7 & 14.0 & Loam \\
\hline Pressure & 1.9 & 5058.2 & 126.3 & 0.0 & 126.2 & Clay loam \\
\hline Soil Core & 8.1 & 73.7 & 38.7 & 3.3 & 35.4 & Sand \\
\hline Soil Core & 3.4 & 344.9 & 34.3 & 0.2 & 34.1 & Loam \\
\hline Soil Core & 13.6 & 206.6 & 68.7 & 1.5 & 67.2 & Clay loam \\
\hline
\end{tabular}

${ }^{\S}$ SD: Standard deviation; GM: Geometric mean; CV: Coefficient of variation (\%); Max: Maximum value; and Min: Minimum value 
Sanjit K. Deb and Manoj K. Shukla / American Journal of Environmental Science 8 (5) (2012) 489-502

Table 7. Comparison of saturated hydraulic conductivity $\left(\mathrm{K}_{\mathrm{s}}^{\S}, \mathrm{mm} \mathrm{h}^{-1}\right)$ measured by different methods (Adapted from Dorsey et al., 1990; Mohanty et al., 1994)
Depth

\begin{tabular}{|c|c|c|c|c|c|c|c|c|}
\hline $\begin{array}{l}\text { Depth } \\
(\mathrm{m})\end{array}$ & Method* & $\begin{array}{l}\text { No. of } \\
\text { measurements }\end{array}$ & $\begin{array}{l}\text { Arithmetic } \\
\text { Mean/Average }\end{array}$ & $\begin{array}{l}\text { Geometric } \\
\text { Mean }^{\S}\end{array}$ & $\begin{array}{l}\mathrm{SD} \\
\text { (ratio) }^{\S}\end{array}$ & SD & $\mathrm{CV}$ & $\mathrm{K}_{\mathrm{s}}$ Range \\
\hline \multicolumn{9}{|c|}{ Dorsey et al. $(1990)^{\dagger}:$} \\
\hline \multirow[t]{4}{*}{0.2} & GP & $5 ; 3$ & $5.9 ; 2.7$ & $3 ; 0.9$ & - & - & - & $0.48-19 ; 0.09-6.8$ \\
\hline & $\mathrm{VP}_{\mathrm{V}}$ & $4 ; 7$ & $24.3 ; 17$ & $23.3 ; 8.7$ & - & - & - & $16-35 ; 2-260$ \\
\hline & $\mathrm{VP}_{\mathrm{H}}$ & $6 ; 4$ & $1.8 ; 2.1$ & $1.4 ; 1.6$ & - & - & - & $0.6-4.5 ; 0.54-3.9$ \\
\hline & $\mathrm{VP}_{\text {ave }}$ & $10 ; 15$ & $10.8 ; 11.6$ & $4.3 ; 4.4$ & - & - & - & $0.6-35 ; 0.2-260$ \\
\hline \multirow[t]{4}{*}{0.4} & GP & $5 ; 2$ & $1.6 ; 0.03$ & $0.74 ; 0.03$ & - & - & - & $0.1-4.3 ; 0.3-0.03$ \\
\hline & $\mathrm{VP}_{\mathrm{V}}$ & $9 ; 7$ & $14.8 ; 7.1$ & $10.3 ; 4.3$ & - & - & - & $0.57-27 ; 0.42-17$ \\
\hline & $\mathrm{VP}_{\mathrm{H}}$ & $6 ; 6$ & $3.4 ; 2.4$ & $2.8 ; 1.5$ & - & - & - & $1.2-6 ; 0.27-6.5$ \\
\hline & $\mathrm{VP}_{\mathrm{ave}}$ & $15 ; 13$ & $10.2 ; 4.9$ & $6.1 ; 2.8$ & - & - & - & $0.57-27 ; 0.27-17$ \\
\hline \multirow[t]{4}{*}{0.6} & GP & $4 ; 3$ & $0.73 ; 0.07$ & $0.55 ; 0.04$ & - & - & - & $0.03-2.3 ; 0.01-0.16$ \\
\hline & $\mathrm{VP}_{\mathrm{V}}$ & $9 ; 5$ & $7.5 ; 4.3$ & $4.4 ; 4.1$ & - & - & - & $0.41-22 ; 0.67-36$ \\
\hline & $\mathrm{VP}_{\mathrm{H}}$ & $6 ; 5$ & $2.7 ; 12$ & $1.5 ; 5.5$ & - & - & - & $0.48-8.7 ; 0.34-25$ \\
\hline & $\mathrm{VP}_{\text {ave }}$ & $15 ; 10$ & $5.6 ; 11$ & $2.9 ; 4.4$ & - & - & - & $0.41-22 ; 0.34-36$ \\
\hline \multirow[t]{6}{*}{ Profile } & GP & $9 ; 5$ & $1.2 ; 0.05$ & $0.65 ; 0.03$ & - & - & - & $0.03-0.16 ; 0.01-0.16$ \\
\hline & $\mathrm{VP}_{\mathrm{V}}$ & $18 ; 12$ & $11.2 ; 5.9$ & $6.7 ; 4.2$ & - & - & - & $0.41-27 ; 0.42-36$ \\
\hline & $\mathrm{VP}_{\mathrm{H}}$ & $12 ; 11$ & $3.1 ; 6.8$ & $2.1 ; 2.7$ & - & - & - & $0.48-8.7 ; 0.27-25$ \\
\hline & $\mathrm{VP}_{\mathrm{ave}}$ & $30 ; 23$ & $8 ; 7.6$ & $4.2 ; 3.5$ & - & - & - & $0.41-27 ; 0.27-36$ \\
\hline & PTM & $2 ; 7$ & $4.6 ; 1.7$ & $4.6 ; 1.6$ & - & - & - & $4.3-4.9 ; 1.3-2$ \\
\hline & Auger & $6 ; 4$ & $4.6 ; 5$ & $2.9 ; 2.5$ & - & - & - & $0.71-13 ; 0.57-13$ \\
\hline \multicolumn{9}{|c|}{ Mohanty et al. (1994): } \\
\hline \multirow[t]{4}{*}{0.15} & GP & - & 3.02 & 1.66 & 0.69 & - & - & $0.36-5.79$ \\
\hline & VP & - & 3.71 & 1.99 & 0.71 & - & - & $0.26-8.92$ \\
\hline & $\mathrm{DP}$ & - & 36.72 & 27.00 & 0.41 & - & - & $13.79-91.08$ \\
\hline & SCM & - & 1.49 & 1.18 & 2.24 & - & - & $0.26-2.74$ \\
\hline \multirow[t]{4}{*}{0.3} & GP & - & 2.87 & 0.25 & 1.41 & - & - & $0.021-11.56$ \\
\hline & VP & - & 10.76 & 6.95 & 0.50 & - & - & $2.79-28.94$ \\
\hline & $\mathrm{DP}$ & - & 83.88 & 55.44 & 0.43 & - & - & $19.44-192.96$ \\
\hline & SCM & - & 50.40 & 39.60 & 2.12 & - & - & $12.024-100.44$ \\
\hline \multirow[t]{5}{*}{0.6} & GP & - & 13.32 & 1.15 & 1.26 & - & - & $0.071-63$ \\
\hline & VP & - & 81.36 & 29.95 & 0.87 & - & - & $2.902-244.08$ \\
\hline & DP & - & 45.36 & 26.93 & 0.46 & - & - & $13.43-142.56$ \\
\hline & DTM & - & 48.60 & 42.12 & 0.25 & - & - & $19.08-72.36$ \\
\hline & SCM & - & 3.64 & 2.67 & 0.36 & - & - & $1.17-6.084$ \\
\hline Across & GP & 16 & 6.70 & 0.92 & 1.01 & 0.0042 & 224 & $0.021-63$ \\
\hline all & VP & 16 & 31.36 & 7.99 & 0.73 & 0.0173 & 198 & $0.26-244.08$ \\
\hline \multirow[t]{3}{*}{ depths } & $\mathrm{DP}$ & 16 & 54.00 & 36.72 & 0.37 & 0.0142 & 94 & 13.43-192.96 \\
\hline & DTM & 3 & 48.60 & 42.12 & 0.25 & 0.0062 & 46 & $19.08-72.36$ \\
\hline & SCM & 11 & 22.28 & 5.80 & 0.79 & 0.0087 & 141 & $0.26-100.44$ \\
\hline
\end{tabular}

* GP: Guelph Permeameter; VP: Velocity Permeameter, where subscripts V, H and ave represent vertical, horizontal and geometric mean of V and H, respectively; PTM: Pumping test method; Auger: Auger hole method; DP: Disk permeameter; DTM: Double-tube method; SCM: Undisturbed soil cores lab method; ${ }^{\dagger}$ Values separated by semicolon indicate data for silt loam and silty clay loam soils, respectively (Dorsey et al., 1990); ${ }^{\S}$ SD: Standard deviation; and CV: Coefficient of variation; and Geometric mean and Standard deviation (ratio) were calculated because the distribution of saturated hydraulic conductivity is lognormal (Mohanty et al., 1994)

In a similar study, Mohanty et al. (1994) evaluated the performance of four in-situ $\mathrm{K}_{\mathrm{s}}$ measuring methods such as the Guelph permeameter, the velocity permeameter, the disk permeameter and the double-tube method at different depths and five locations on a glacial-till soil. The Guelph permeameter method gave the lowest $\mathrm{K}_{\mathrm{s}}$ values because of small sample size, whereas the disk permeameter and double-tube methods gave maximum values for $\mathrm{K}_{\mathrm{s}}$ with minimum variability, likely due to the large sample size (Table 7). Maximum variability in $\mathrm{K}_{\mathrm{s}}$ values for soil cores at shallow depths was attributed to the presence or absence of open-ended macropores. However, estimates of $\mathrm{K}_{\mathrm{s}}$ were most comparable for the velocity permeameter and the laboratory method using a constant-head permeameter.

\subsection{Influence of Land Use on Saturated Hydraulic Conductivity}

Several accounts are available using different measurement devices to demonstrate that land use has a strong influence on the variability of soil hydraulic conductivity. The steady state hydraulic conductivity was measured by a double ring infiltrometer and soil core method in the lab under three different land uses, i.e., annual tillage by chiseling or mold board plowing, no-tillage (6-15 years) and woodland (Reynolds et al., 2000; Table 8). 


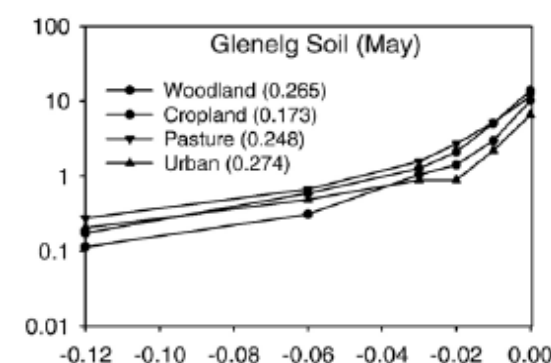

(a)

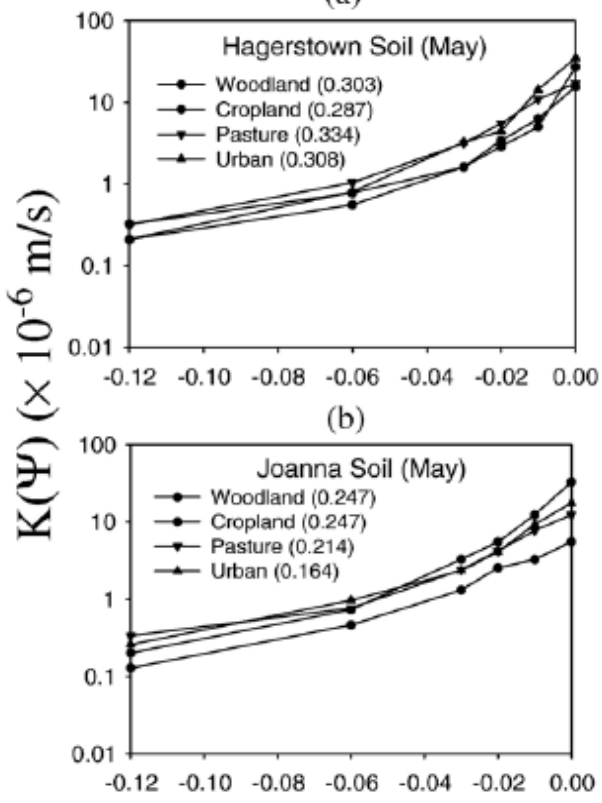

(c)

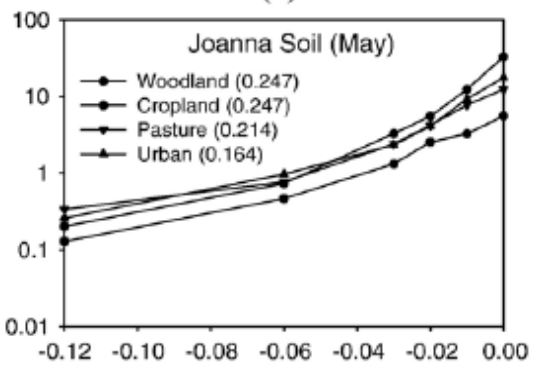

(d)

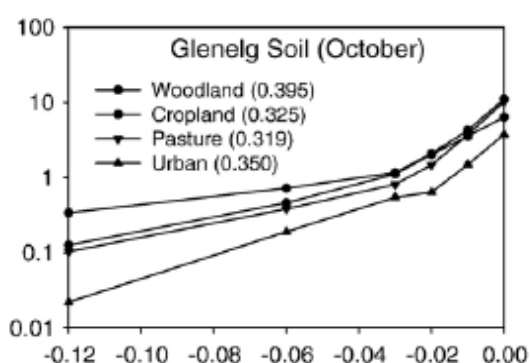

(e)

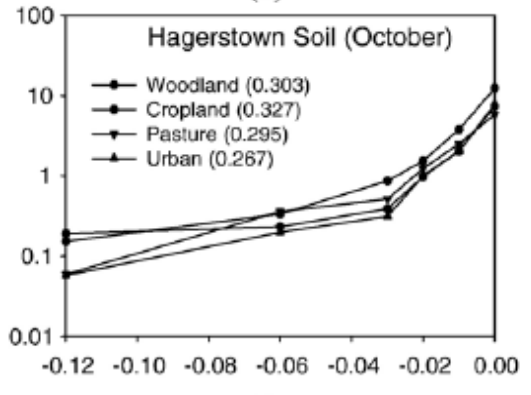

(f)

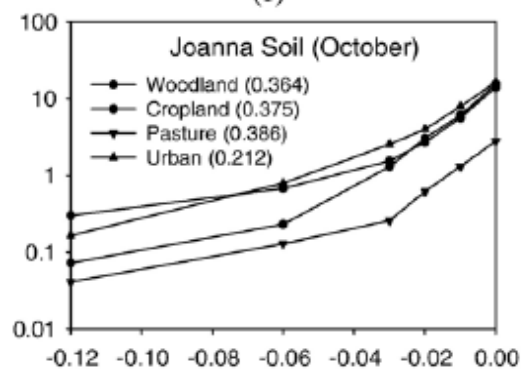

(g)

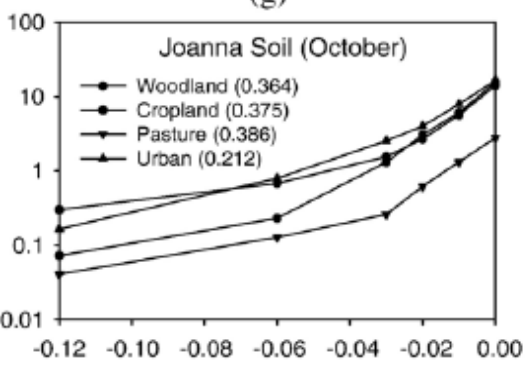

(h)

\section{Supplied water potential (m)}

Fig. 2: Soil hydraulic conductivity as a function of water potential $[K(\Psi)]$ among the four land uses (woodland, cropland, pasture and urban) within each of the four soil series (Glenelg, Hagerstown, Joanna and Morrison) measured in May (a-d) and October (e-h), respectively. The number in parenthesis is the averaged initial volumetric soil moisture at each site in May or October (Zhou et al., 2008). (Reprinted with permission from Elsevier)

Both $\mathrm{K}_{\mathrm{s}}$ and steady state infiltration rate were higher from woodland than agricultural fields and steady state infiltration rate values varied in the order: woodland > no-tillage >annual tillage. Such a trend is not surprising because of the higher macroporosity of the soils of the natural woodland than soils under no-tillage or conventional tillage system. The tension infiltrometer seemed to underestimate $\mathrm{K}_{\mathrm{s}}$ values for sand under all three land management systems. A possible explanation could be the restriction to flow from tubes or air in the mariotte bottle used to supply water. Other possible reasons could be the arrangement of macropores, three dimensional infiltration and restrictions to flow by the membrane (Reynolds et al., 2000). 


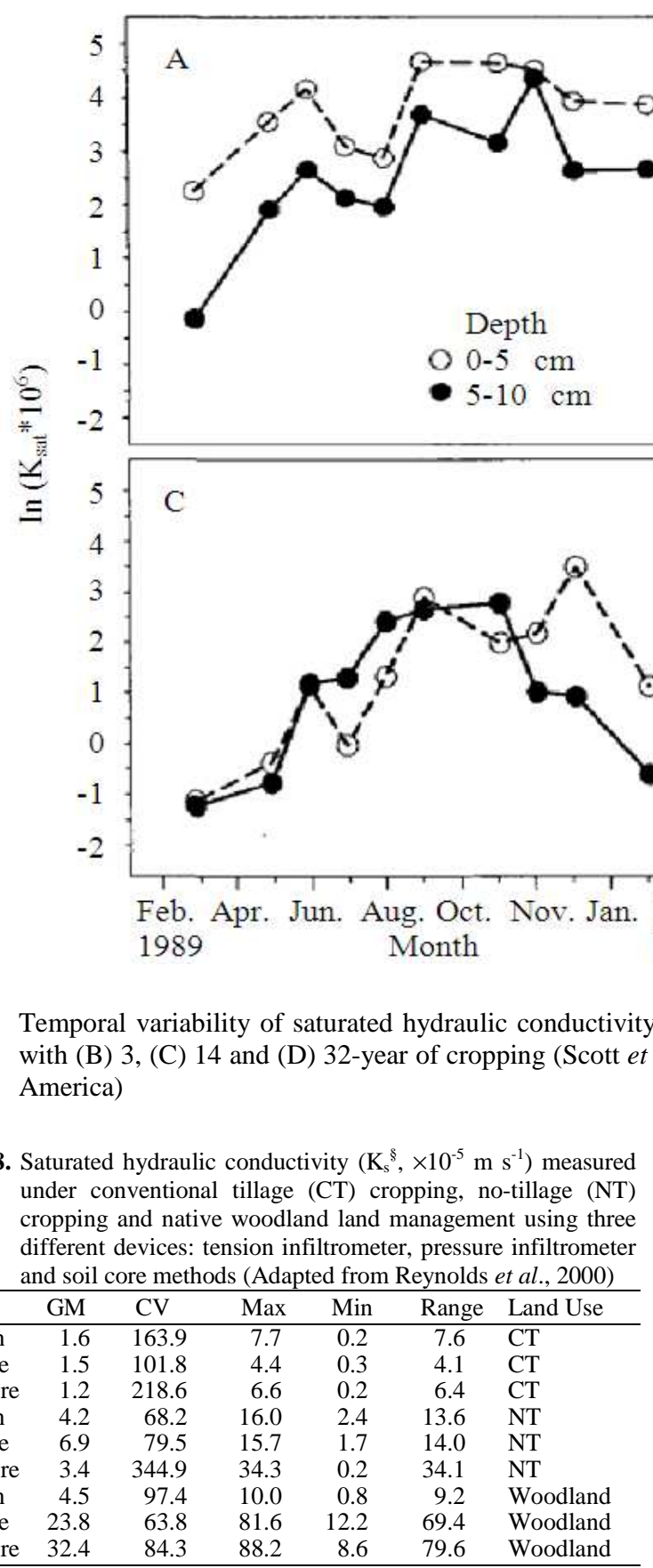

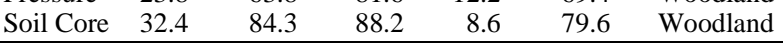

${ }^{\S}$ GM: Geometric mean; CV: Coefficient of variation; Max: Maximum value; and Min: Minimum value

Table 9. Saturated hydraulic conductivity $\left(\mathrm{K}_{\mathrm{s}}^{\S}, \mathrm{cm} \mathrm{h}^{-1}\right)$ measured in the laboratory using soil cores for some fields under Conventional Tillage (CT) (using chisel, moldboard), NoTillage (NT) (6-15 years) and woodland land uses in Ohio (modified from Shukla and Lal, 2005)

\begin{tabular}{llllrll}
\hline Device & Mean & CV & Max & Min & Range & Land Use \\
\hline Soil Core & 48.1 & 0.76 & 101.7 & 0.6 & 101.0 & CT \\
Soil Core & 26.7 & 2.03 & 327.4 & 0.1 & 327.3 & NT \\
Soil Core & 85.7 & 0.80 & 178.0 & 10.1 & 167.9 & Woodland \\
\hline
\end{tabular}

${ }^{\S} \mathrm{CV}$ : Coefficient of variation (\%); Max: Maximum value; and Min: Minimum value

Table 8. Saturated hydraulic conductivity $\left(\mathrm{K}_{\mathrm{s}}^{\S}, \times 10^{-5} \mathrm{~m} \mathrm{~s}^{-1}\right)$ measured cropping and native woodland land management using three different devices: tension infiltrometer, pressure infiltrometer

\begin{tabular}{lrrrrrl}
\hline Device & GM & \multicolumn{1}{c}{ CV } & Max & Min & Range & Land Use \\
\hline Tension & 1.6 & 163.9 & 7.7 & 0.2 & 7.6 & CT \\
Pressure & 1.5 & 101.8 & 4.4 & 0.3 & 4.1 & CT \\
Soil Core & 1.2 & 218.6 & 6.6 & 0.2 & 6.4 & CT \\
Tension & 4.2 & 68.2 & 16.0 & 2.4 & 13.6 & NT \\
Pressure & 6.9 & 79.5 & 15.7 & 1.7 & 14.0 & NT \\
Soil Core & 3.4 & 344.9 & 34.3 & 0.2 & 34.1 & NT \\
Tension & 4.5 & 97.4 & 10.0 & 0.8 & 9.2 & Woodland \\
Pressure & 23.8 & 63.8 & 81.6 & 12.2 & 69.4 & Woodland \\
Soil Core & 32.4 & 84.3 & 88.2 & 8.6 & 79.6 & Woodland \\
\hline § GM: Geometric mean; CV: Coefficient of variation; Max: Maximum
\end{tabular}

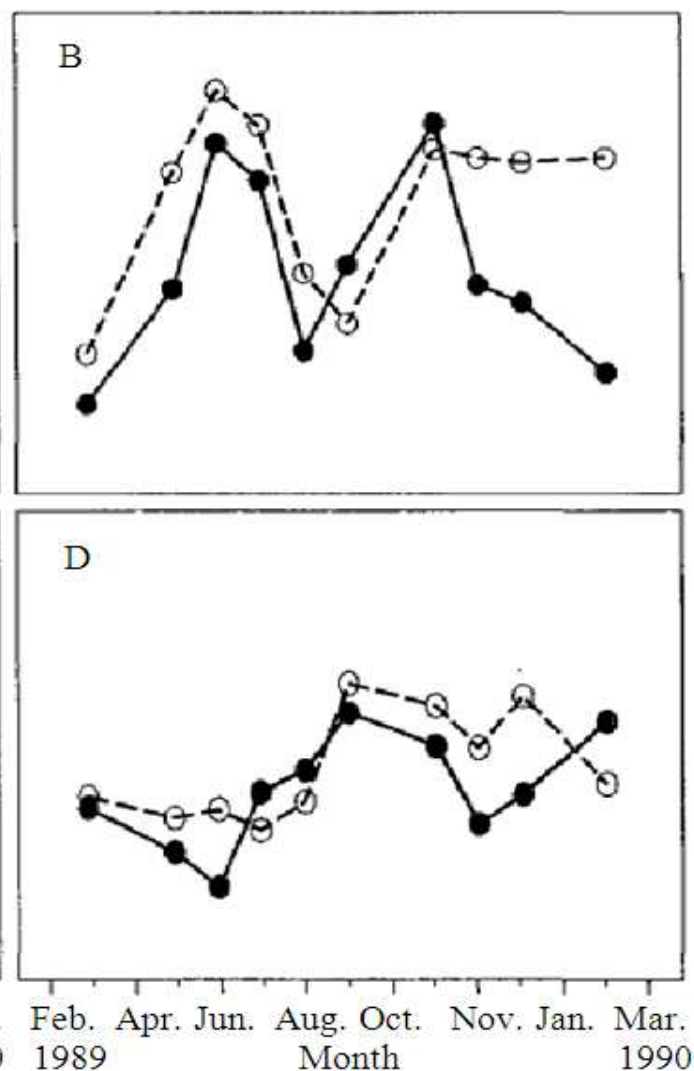

Fig. 3. Temporal variability of saturated hydraulic conductivity at two soil depths $(0-5 \mathrm{~cm}$ and $5-10 \mathrm{~cm})$ in $(\mathrm{A})$ prairie and fields

However, average $\mathrm{K}_{\mathrm{s}}$ values did not follow the conventional wisdom and were higher for fields under conventional tillage than no-tillage in the other study in Ohio (Table 9). This could be due to a number of factors including the larger sample size used for determining the $\mathrm{K}_{\mathrm{s}}$ from no-tillage fields than from fields under annual tillage, measurement errors in the field and laboratory while collecting and preparing the core samples, timing of tillage operations and errors during sample analyses.

Difference of hydraulic conductivity and their temporal dynamics were examined among four land uses (woodland, cropland, pasture and urban) and four soil series (Glenelg, Hagerstown, Joanna and Morrison) in Pennsylvania with contrasting textures, structures and parent materials (Zhou et al., 2008). At each of the 16 sites of soil series-land use combinations, Zhou et al. (2008) measured field-saturated and near-saturated hydraulic conductivities during May and October 2004 to 2006 using tension infiltrometers at water potentials of $-0.12,-0.06,-0.03,-0.02,-0.01$ and $0 \mathrm{~m}$ (Fig. 2). The measurement time had the greatest impact on measured hydraulic conductivities, followed by the land use and soil series. 


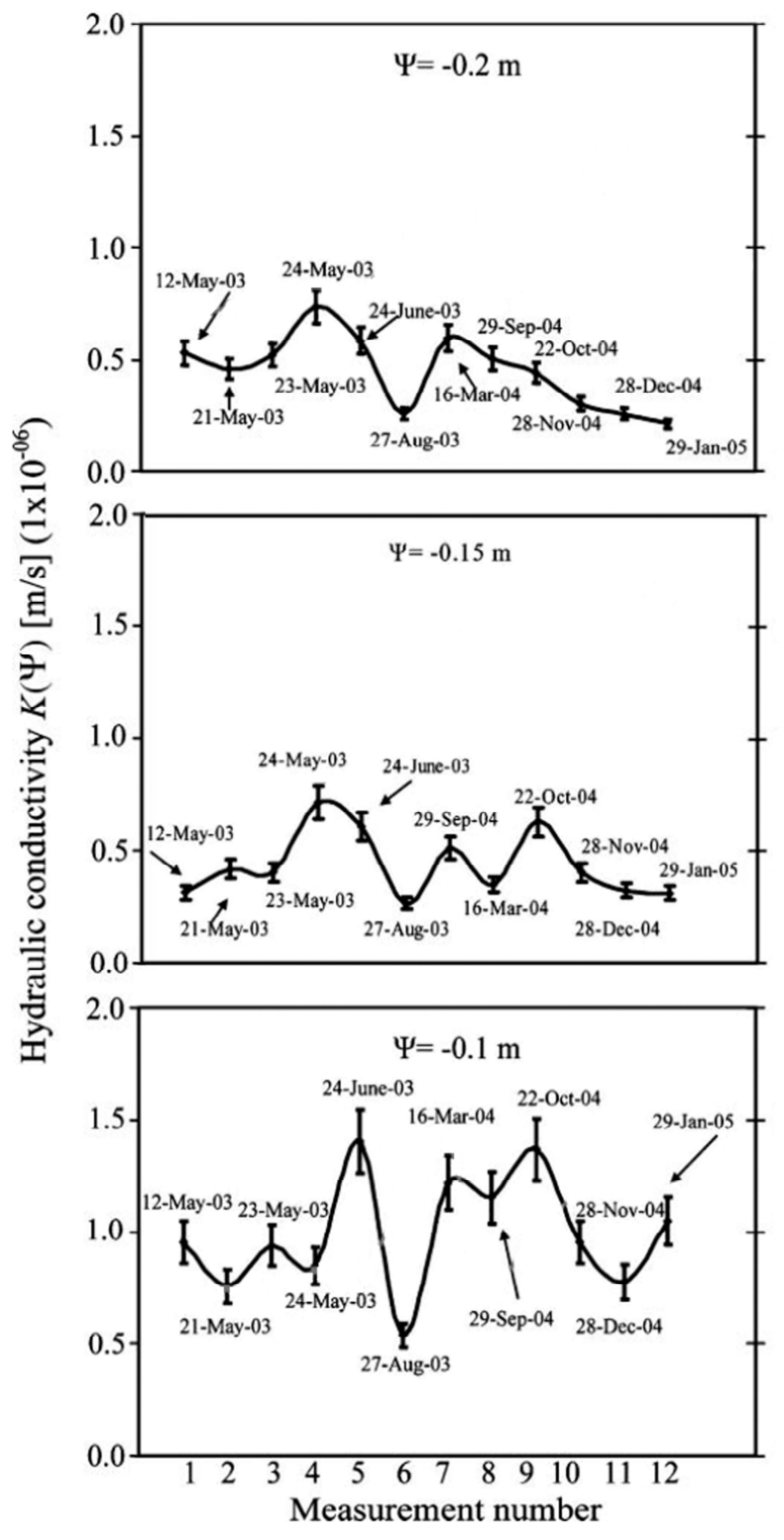

Fig. 4. Temporal variations of hydraulic conductivity $[K(\Psi)]$ at varying matric potentials $(\Psi=-0.2,-0.15$ and $-0.1 \mathrm{~m})$. The average values for both 0.2 and $0.24 \mathrm{~m}$ disk diameters are presented, together with $10 \%$ error bars, because the means for both disk sizes were statistically similar. (Modified from Gupta et al., 2006). (Reprinted with permission from Soil Science Society of America).

Compared to the cropland, pasture and urban land uses, woodland showed less temporal change because of less human-induced impacts and more consistent ground cover.

\subsection{Temporal Variability of Saturated Hydraulic Conductivity}

The temporal variability of $\mathrm{K}_{\mathrm{s}}$ was determined by several researchers. For example, Scott et al. (1994) studied short- and long-term variability of $\mathrm{K}_{\mathrm{s}}$ in four adjacent fields located in Arkansas, USA. One of the fields was under prairie while other three cropped fields had mostly been in a rice-soybean rotation for either 3, 14, or 32 years (Scott et al., 1994). The fields were sampled monthly from March 1989 to March 1990. The $\mathrm{K}_{\mathrm{s}}$ was measured on intact soil cores in the laboratory using constant head method and the temporal variability of $\mathrm{K}_{\mathrm{s}}$ is presented in Fig. 3. Scott et al. (1994) defined the variability among fields as long-term and the variability among sampling times within a field as short-term. 
Table 10. Spatial variability of saturated hydraulic conductivity $\left(\mathrm{K}_{\mathrm{s}}^{*}\right)$ presented using semivariogram parameters for an experimental farm, Austria (Shukla et al., 2004), a 162-ha cotton field Perthshire, Mississippi, USA (Iqbal et al., 2005), a 12-ha field in Kingston, North Carolina, USA (Duffera et al., 2007) and a 40-ha field in Las Cruces, New Mexico, USA (Sharma et al., 2011)

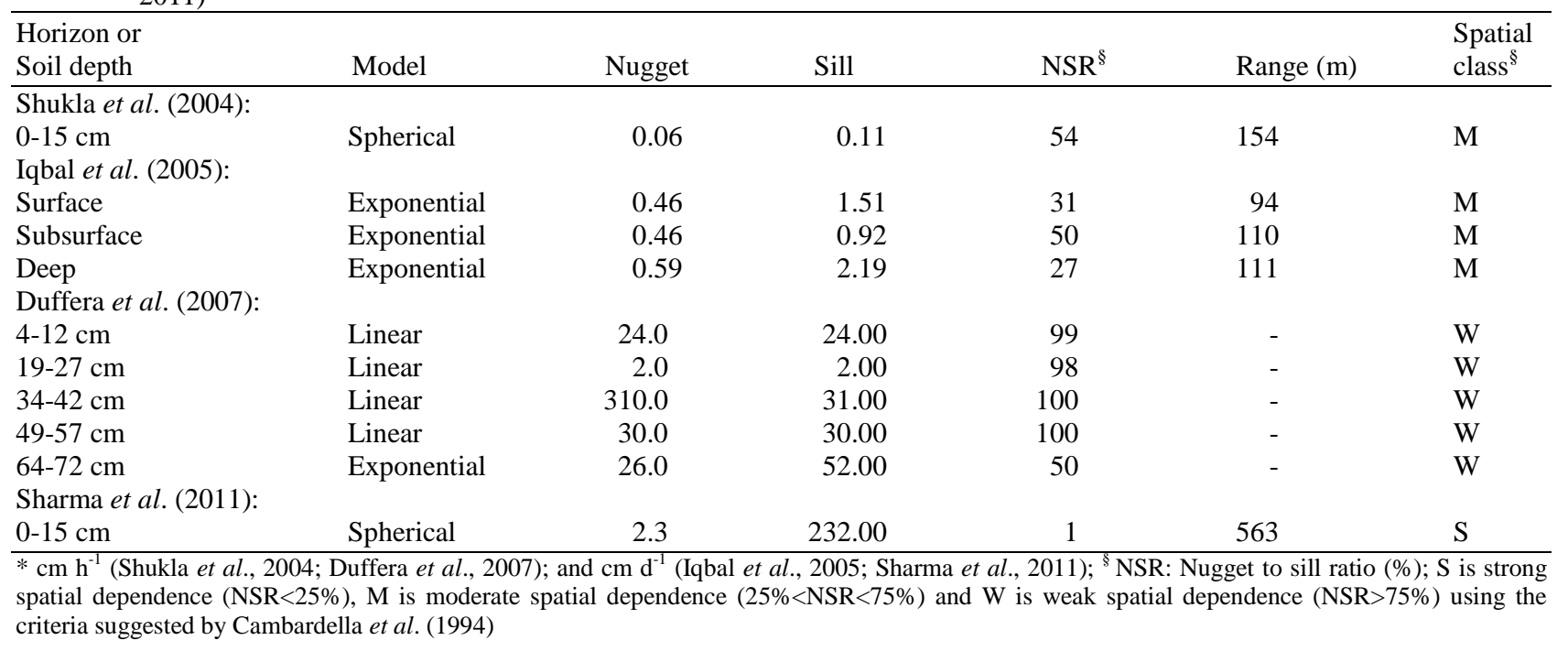

The short-term temporal variability of $\mathrm{K}_{\mathrm{s}}$ in the 3,14 and 32-year fields resulted from seasonal changes and crop management practices (e.g., irrigation of soybeans, flooding of rice, tillage, disking), while the short-term variability of $\mathrm{K}_{\mathrm{s}}$ in the prairie resulted from climate influences on the biological activities of the grasses and microorganisms. Although not consistent, in general a pattern emerged and $\mathrm{K}_{\mathrm{s}}$ values started increasing from spring until early summer, remained similar until early winter and then decreased. During the years when the field was disked, the monthly trends of $\mathrm{K}_{\mathrm{s}}$ changed. Scott et al. (1994) reported that the relatively high $\mathrm{K}_{\mathrm{s}}$ during June and November 1989 was due to the unstable, loose aggregation of the soil due to tillage.

Another study on the temporal variability of unsaturated hydraulic conductivity, $\mathrm{K}(\Psi)$, was by Gupta et al. (2006). They applied six different matric potentials of $-0.2,-0.15,-0.1,-0.05,-0.02$ and $0 \mathrm{~m}$ using 0.2 and $0.24 \mathrm{~m}$ disks. The observations were made during a 21month period for May 2003 to January 2005 on an abandoned agricultural in Texas, USA. The temporal variability of $\mathrm{K}(\Psi)$ at varying matric potentials $(-0.2,-0.15$ and $-0.1 \mathrm{~m})$ is depicted in Fig. 4 as an example. The average values from these two disks showed remarkable temporal variation in $\mathrm{K}(\Psi)$.

\subsection{Spatial Variability of Saturated Hydraulic Conductivity}

It is commonly known that most soil hydrological properties exhibit both short and long range variability (Nielsen et al., 1973). It has been generally accepted that samples collected close to each other are more similar than those collected at greater distances. The similarity decreases as the separation distance between samples increases up to a certain separation distance beyond which samples are known as spatially uncorrelated or independent. Spatial dependence is reported to occur at scales ranging from a few meters to several kilometers (Trangmar et al., 1987; Ovalles and Collins, 1988; Gaston et al., 2001). Geostatistical analysis is usually carried out to understand the spatial structure and spatial variability of soil hydrological properties. Geospatial analysis can also provide more insight on spatial variability of a property whether it is structured, unstructured or directional. A detailed overview of these methods and their application on field datasets can be found in Hillel (1980); Webster (1985) and Nielsen and Wendroth (2003).

A study was conducted at the experimental farm of University of Natural Resources and Applied Sciences, Austria to determine the spatial variability of $\mathrm{K}_{\mathrm{s}}$ of the soil (Table 10; Shukla et al., 2004). In-situ $\mathrm{K}_{\mathrm{s}}$ was determined using Guelph permeameter and the variability was identified as moderate using the nugget ratio criteria of Cambardella et al. (1994). In a study on a 162-ha cotton field near Perthshire, Mississippi, spatial variability of $\mathrm{K}_{\mathrm{s}}$ was determined using falling head method (Iqbal et al., 2005). Table 10 shows that the $\mathrm{K}_{\mathrm{s}}$ had a nugget ratio ranging from $0.25-0.75$ and using the criteria suggested by Cambardella et al. (1994) and Iqbal et al. (2005) classified them as moderate spatial dependent. In spite of the similarity of Nugget to Sill Ratio (NSR), various physical properties displayed wide variations in their range of spatial dependence. Although this research provided very useful information on the structure of the variability and spatial dependence of a 
soil property, the question, what could be the best sampling strategy for collecting samples for analyzing various soil properties that are spatially independent or uncorrelated, was not definitively answered. The differences in spatial class and range of spatial dependence among different horizons also indicated to the large inherent spatial variability of soil properties in general.

Similarly, spatial variability of $\mathrm{K}_{\mathrm{s}}$ was assessed for a 12-ha field in Kingston, North Carolina and spatial dependence was described using Cambardella et al. (1994) Classification (Table 10). The spatial dependence of $K_{s}$ has been also reported for surface soil $(0-15 \mathrm{~cm})$ in an agricultural field located in southern New Mexico (Sharma et al., 2011; Table 10). The important difference between different datasets presented in Table 10 is that spatial variability of $\mathrm{K}_{\mathrm{s}}$ was reported as moderate by Shukla et al. (2004) and Iqbal et al. (2005), weak by Duffera et al. (2007) and strong by Sharma et al. (2011). Looking at the CV (Table 2 for some of the data), in these studies $\mathrm{K}_{\mathrm{s}}$ was reported always as highly variable. The data in several of the tables in this review showed no stochastic correlation between the $\mathrm{CV}$ and the size of the field or $\mathrm{CV}$ and the range of dependence. This could be due to the small sample size but could also be due to the multi-scale variability of $\mathrm{K}_{\mathrm{s}}$ across these domains.

Since $K_{s}$ is an important parameter for water and solute application efficiencies and triggering GHG (greenhouse gas) emissions from an ecosystem, knowledge of the spatial structure and spatial variability on a landscape scale is a prerequisite for designing site specific management. In order to conserve the water (surface and groundwater) resources and use the available water efficiently without polluting the water resources, as well as to prevent or minimize GHG emissions from the agricultural fields, there is a need to increase the overall on-farm water application and water use efficiency. Accordingly, an accurate knowledge of the variability of the $K_{s}$ is a prerequisite for initiating an efficient water management scheme.

\section{CONCLUSION}

In this review, the variability of hydraulic conductivity due to a large number of factors is presented. The spatial and temporal variability of hydraulic conductivity centered on the statistical variability of hydraulic conductivity and the influences of sample support, measurement devices/methods, soils, land uses and agricultural management on hydraulic conductivity are reviewed and discussed. The spatial and temporal variation of hydraulic conductivity and interactions among soil characteristics, land uses, agricultural management, climatic and environmental conditions and measurement methods are rather complex, which should take into account multiple factors discussed in this review and one must adequately assess a representative value. Notably, hydraulic conductivity measured in the field could show a much larger/smaller variability than those measured in the laboratory because of hitting or missing of macropore channels or error associated with the measurement. Since the design and functioning of the soil-water-plant hydrological systems depends to a great extent on the soil's hydraulic conductivity, decisions and choices made by investigators during sampling, sampling designs, availability of resources, number of investigators involved in sampling and analysis, skill level of investigators, type and quality of tools and equipments used to collect samples and analyses, scale of the domain, availability of time, accessibility of sites, criteria of success and assumptions made for the sampling and analysis have profound influence on the variability of hydraulic conductivity.

\section{ACKNOWLEDGEMENT}

Funding for the work was provided by New Mexico State University Agricultural Experiment Station and authors thank them for the support.

\section{REFERENCES}

Bagarello, V. and G. Provenzano, 1996. Factors affecting fild and laboratory measurement of saturated hydraulic conductivity. Trans. Am. Soc. Agric. Eng.

Bagarello, V., 1997. Influence of well preparation on field-saturated hydraulic conductivity measured with the guelph permeameter. Geoderma, 80: 169-180. DOI: 10.1016/S0016-7061(97)00051-7

Biggar, J.W. and D.R. Nielsen, 1976. Spatial variability of the leaching characteristics of a field soil. Water Resources Res., 12: 78-84. DOI: 10.1029/WR012i001p00078

Brooks, R.H. and A.T. Corey, 1964. Hydraulic properties of porous media. Hydrology Paper 3. Colorado State University, Fort Collins.

Burdine, N.T., 1953. Relative permeability calculations from pore size distribution data. J. Petroleum Technol., 5: 71-78

Cambardella, C.A., T.B. Moorman, T.B. Parkin, D.L. Karlen and J.M. Novak et al., 1994. Field-scale variability of soil properties in central Iowa soils. Soil Sci. Soc. Am. J., 58: 1501-1511.

Campbell, G.S., 1974. A simple method for determining unsaturated conductivity from moisture retention data. Soil Sci., 117: 311-314. DOI: 10.1097/00010694-197406000-00001

Dane, J.H. and C. Topp, 2002. Methods of Soil Analysis. 1st Edn., Soil Science Society of America, Madison, WI, ISBN-10: 089118841X, pp: 866. 
Davidson, J.M., L.R. Stone, D.R. Nielsen and M.E. Larue, 1969. Field Measurement and Use of SoilWater Properties. Water Resour. Res., 5: 1312-1321. DOI: 10.1029/WR005i006p01312

Dorsey, J.D., A.D. Ward, N.R. Fausey and E.S. Bair, 1990. A comparison of four field methods for measuring saturated hydraulic conductivity. Trans. Am. Soc. Agric. Eng., 33: 1925-1931.

Duffera, M., J.G. White and R. Wesz, 2007. Spatial variability of Southeastern U.S. Coastal Plain soil physical properties: Implications for site-specific management. Geoderma, 137: 327-339. DOI: 10.1016/j.geoderma.2006.08.018

Gardner, W.R., 1958. Some steady-state solutions of the unsaturated moisture flow equation with application to evaporation from a water table. Soil Sci., 85: 228232.

Gaston, L.A., M.A. Locke, R.M. Zablotowicz and K.N. Reddy, 2001. Spatial variability of soil properties and weed populations in the Mississippi delta. Soil Sci. Soc. Am. J., 65: 449-459.

Gupta, S., B.P. Mohanty and J.M. Köhne, 2006. Soil hydraulic conductivities and their spatial and temporal variations in a vertisol. Soil Sci. Soc. Am. J., 70: 1872-1881. DOI: 10.2136/sssaj2006.0201

Hern, S.C. and S.M. Melancon, 1986. Vadose Zone Modeling of Organic Pollutants. 1st Edn., Lewis Publishers, Chelsea, Mich., ISBN-10: 0873710428, pp: 295.

Hillel, D., 1980. Applications of Soil Physics. 1st Edn., Academic Press, New York, ISBN-10: 0123485800, pp: 385 .

Ikemura, Y., M.K. Shukla, M. Tahboub and B. Leinauer, 2008. Some physical and chemical properties of soil in organic and conventional farms for a semi-arid ecosystem of New Mexico. J. Sustain. Agric., 31: 149-170. DOI: 10.1300/J064v31n04_10

Iqbal, J., J.A. Thomasson, J.N. Jenkins, P.R. Owens and F.D. Whisler, 2005. Spatial variability analysis of soil physical properties of alluvial soils. Soil Sci. Soc. Am. J., 69: 1338-1350.

Isaaks, E.H. and R.M. Srivastava, 1989. An Introduction to Applied Geostatistics. 1st Edn., Oxford University Press, USA., pp: 561.

Lal, R., 2004. Principles of Soil Physics. 1st Edn., CRC Press, ISBN-10: 0824751272, pp: 528.

Leong, E.C. and H. Rahardjo, 1997. Permeability functions for unsaturated soils. J. Geotechnical Geoenvironmental Eng., 123: 1118-1126.

Mason, D.D., J.F. Lutz and R.G. Petersen, 1957. Hydraulic conductivity as related to certain soil properties in a number of great soil groups-sampling errors involved. Soil Sci. Soc. Am. J., 21: 554-560.

Mohanty, B.P., R.S. Kanwar and C.J. Everts, 1994. Comparison of saturated hydraulic conductivity measurement methods for a glacial-till soil. Soil Sci. Soc. Am. J., 58: 672-677.
Mualem, Y., 1976. A new model for predicting the hydraulic conductivity of unsaturated porous media. Water Resources Res., 12: 513-522. DOI: 10.1029/WR012i003p00513

Nielsen, D. and O. Wendroth, 2003. Spatial and Temporal Statistics: Sampling Field Soils and their Vegetation. 1st Edn., Catena-Verlag, Reiskirchen, Germany, ISBN-10: 1593262590, pp: 398.

Nielsen, D.R., J.W. Biggar and K.T. Erh, 1973. Spatial variability of field-measured soil-water properties. Hilgardia, 42: 215-259.

Norton, E.A., 1939. Soil Conservation Survey Handbook. 1st Edn., United States Department of Agriculture, Washington, D.C., pp: 40

Ovalles, F.A. and M.E. Collins, 1988. Evaluation of soil variability in northwest florida using geostatistics. Soil Sci. Soc. Am. J., 52: 1702-1708.

Parkin, T. and J. Robinson, 1992. Analysis of lognormal data. Adv. Soil Sci., 20: 193-235.

Polubarinova-Kochina, P.Y., 1962. Theory of Ground Water Movement. 1st Edn., Books on Demand, Berlin, ISBN-10: 0691080488, pp: 635.

Reynolds, W.D., B.T. Bowman, R.R. Brunke, C.F. Drury and C.S. Tan, 2000. Comparison of tension infiltrometer, pressure infiltrometer and soil core estimates of saturated hydraulic conductivity. Soil Sci. Soc. Am. J., 64: 478-484.

Richards, L.A., 1931. Capillary conduction of liquids through porous mediums. Physics, 1: 318-333. DOI: $10.1063 / 1.1745010$

Richards, L.A., 1952. Report on the subcommittee on permeability and infiltration, committee on terminology, soil science society of America. Soil Sci. Soc. Am. J., 16: 85-88. DOI: 10.2136/sssaj1952.03615995001600010025x

Rijtema, P.E., 1965. An analysis of actual evapotranspiration. Agric. Res. Rep., 659: 1-107.

Schilfgaarde, J.V., 1974. Drainage for Agriculture. 1st Edn., American Society of Agronomy, Madison, WI, pp: 700.

Scott, H.D., A. Mauromoustakos, I.P. Handayani and D.M. Miller, 1994. Temporal variability of selected properties of loessial soil as affected by cropping. Soil Sci. Soc. Am. J., 58: 1531-1538.

Sharma, P., M.K. Shukla and J.G. Mexal, 2011. Spatial Variability of Soil Properties in Agricultural Fields of Southern New Mexico. Soil Sci., 176: 288-302. DOI: $10.1097 /$ SS.0b013e31821c0dab

Shukla, M.K. and R. Lal, 2005. Erosional effects on soil physical properties in an on-farm study on alfisols in West Central Ohio. Soil Sci., 170: 445-456.

Shukla, M.K., 2011. Soil Hydrology, Land Use and Agriculture: Measurement and Modelling. 1st Edn., CABI, Wallingford, Oxfordshire, ISBN-10: 184593797X, pp: 448. 
Shukla, M.K., B. Slater, R. Lal and P. Cepuder, 2004. Spatial variability of soil properties and potential management classification of a chernozemic field in Lower Aus. Soil Sci., 169: 852-860.

Shukla, M.K., R. Lal and M. Ebinger, 2003a. Tillage effects on physical and hydrological properties of a typic argiaquoll in Central Ohio. Soil Sci., 168: 802811.

Shukla, M.K., R. Lal, L.B. Owens and P. Unkefer, 2003b. Land Use and Management Impacts on Structure and Infiltration Characteristics of Soils in the North Appalachian Region of Ohio. Soil Sci., 168: 167-177.

Slichter, C.S., 1899. Theoretical Investigation of the Motion of Ground Waters. 1st Edn., Geological Survey, Washington, D.C., pp: 90.

SSDS, 1993. Soil survey manual. United States Department of Agriculture, Soil Conservation Service.

Stephens, D.B., 1996. Vadose Zone Hydrology. 1st Edn., Taylor and Francis, Boca Raton, Florida, ISBN-10: 0873714326, pp: 347.

Stockton, J.G. and A.W. Warrick, 1971. Spatial variability of unsaturated hydraulic conductivity. Soil Sci. Soc. Am. J., 35: 847-848.
Trangmar, B.B., R.S. Yost, M.K. Wade, G. Uehara and M. Sudjadi, 1987. Spatial variation of soil properties and rice yield on recently cleared land. Soil Sci. Soc. Am. J., 51: 668-674.

Uhland, R.E. and A.M. O'Neal, 1951. Soil Permeability Determinations for Use in Soil and Water Conservation. 1st Edn., U.S.D.A. Soil Conservation Service, Washington, D.C., pp: 36.

Webb, T.H., J.J. Claydon and S.R. Harris, 2000. Quantifying variability of soil physical properties within soil series to address modern land-use issues on the Canterbury Plains, New Zealand. Aus. J. Soil Res., 38: 1115-1129.

Webster, R., 1985. Quantitative spatial analysis of soil in the field. Adv. Soil Sci., 3: 1-70.

Wind, G.P., 1955. A field experiment concerning capillary rise of moisture in a heavy clay soil. Netherlands J. Agric. Sci., 3: 60-69.

Zhou, X., H.S. Lin and E.A. White, 2008. Surface soil hydraulic properties in four soil series under different land uses and their temporal changes. Catena, 73: 180-188. DOI: 10.1016/j.catena.2007.09.009 